\title{
FACTORS THAT IMPACT KNOWLEDGE DISSEMINATION IN PROJECTS
}

\author{
J.W. Prinsloo ${ }^{1 \#,}$ C.C. van Waveren ${ }^{1} \&$ K.-Y. Chan ${ }^{1 *}$
}

\section{ARTICLE INFO}

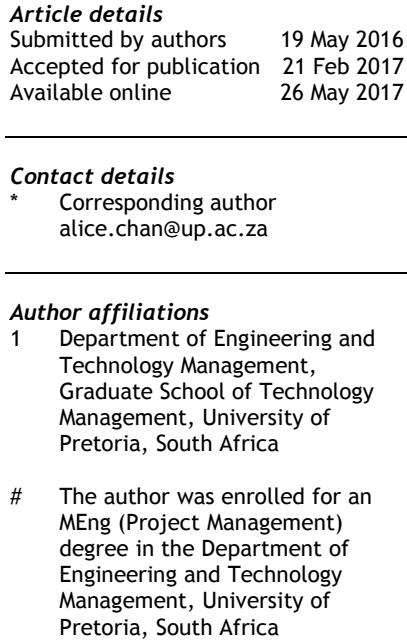

\# The author was enrolled for an MEng (Project Management) degree in the Department of Engineering and Technology Management, University of Pretoria, South Africa

DOI

http://dx.doi.org/10.7166/28-1-1566

\section{ABSTRACT}

Knowledge dissemination, as part of the knowledge exchange process, is particularly challenging in any project environment due to the temporary nature of projects. Although several studies in the earlier literature studied the factors that influence knowledge exchange, very few examined them from the 'knowledge push' perspective. This study aims, therefore, to highlight the critical factors that impact knowledge dissemination in a project environment. This empirical research found ten critical factors, such as individual experience, trust, source credibility, shared understanding, motivation, and articulability. These individual factors seem to have a dominant influence on knowledge dissemination from the view point of the knowledge source.

\section{OPSOMMING}

Kennisverspreiding, as deel van die kennis uitruilproses, is besonders uitdagend in enige projek omgewing as gevolg van die tydelike aard van die projekte. Alhoewel verskeie studies in die literatuur die faktore wat kennis uitruiling beïnvloed, bestudeer het, is daar min studies wat dit vanuit 'n "kennisuitstoot" perspektief oorweeg. Hierdie artikel lig dus om die kritiese faktore wat kennis verspreiding in 'n projek omgewing beïnvloed, uit. Hierdie empiriese navorsing het tien faktore identifiseer, onder andere individuele ervaring, vertroue, bronbetroubaarheid, gedeelde verstaan, motivering en artikuleerbaarheid. Hierdie individuele faktore blyk om ' $\mathrm{n}$ dominante invloed op die kennis verspreiding vanuit die oogpunt van kennisbron te hê.

\section{INTRODUCTION}

Sankarasubramanian [1] stated that 'knowledge' is the one thing that is common to all projects, as it is the most important resource needed for project management. Knowledge may be understood as "experiences, contextual comprehension, value-added information, or insights based on frameworks of understanding that reside in the minds of individuals or groups" [2]. Research on knowledge management in project environments has received considerable attention (e.g. [3],[4]). Knowledge management in a project situation is not limited to knowledge within projects, but is also about knowledge between different projects [5]. Knowledge management is defined by O'Dell and Grayson [6] as "a conscious strategy for moving the right knowledge to the right people at the right time, to... improve organizational performance". This definition stresses the importance of distributing knowledge, and therefore implies that knowledge dissemination is a crucial part of knowledge management [7]. It is important in the project environment to disseminate project management experiences and lessons learned in order to avoid repeating the same mistakes in the projects that follow [8]. However, knowledge dissemination is difficult in project-based organisations due to the inherent properties of projects, such as time constraints and knowledge discontinuity [9], or team members being temporary, or lack of mutual social awareness [10]. Another challenge that is specific to the transfer of knowledge from one project to another is the shortage of learning mechanisms [11]. Furthermore, Almeida and Soares [12] indicated that the ineffectiveness in knowledge sharing between project teams is perhaps the most prominent issue that must be dealt with. It impacts learning, knowledge sharing and therefore the knowledge gets 
trapped. Knowledge transfer in projects is critical to ensuring that the project is a success, measured by meeting the scope, time, cost, and quality of the project [13]. Recognising the importance of knowledge transfer to the success of the project, one could ask why more time isn't spent on ensuring correct knowledge dissemination, as project failure became more evident in the $20^{\text {th }}$ century. One answer is that there is little or no knowledge dissemination [14].

Despite the importance of knowledge management and project management, there is limited empirical research that combines both fields [15]. Although success factors for, and barriers to, knowledge management in and between projects have been studied (e.g. [4]), they are not specific to knowledge dissemination - which is an important process in project-based organisations. The main objectives of this study are to identify and prioritise the factors that impact knowledge dissemination in projects from a knowledge source point of view, and to contribute to the research and practice in project and knowledge management. By exploring these factors, this study can improve knowledge dissemination in projects, and as a result can improve project management practices and project outcomes.

In order to address the research problem, the following associated research questions are addressed:

(1) What are the factors that impact knowledge dissemination in projects?

(2) Which factors have the most influence on knowledge dissemination in projects?

The remainder of this paper is structured as follows. Section 2 clarifies the definition of 'knowledge dissemination' used in this study along with other commonly-used terms such as 'knowledge transfer', 'knowledge sharing', and 'knowledge exchange'. Then the authors use an exploratory research approach by conducting a comprehensive qualitative literature study to identify factors that impact knowledge dissemination. Section 3 describes the research methodology and the finalised list of factors to be tested in the survey. Section 4 describes the results that identify the top ten critical factors. Section 5 provides concluding remarks with some managerial implications and suggestions for future study.

\section{FACTORS IMPACTING KNOWLEDGE DISSEMINATION}

In order to identify the factors, it is important to understand the process of knowledge dissemination. Kasvi and others [16] examined the management of project knowledge in a project environment in four groups of activities: (1) knowledge creation, (2) knowledge administration, (3) knowledge dissemination, and (4) knowledge utilization and productisation. They further specified that knowledge dissemination occurs both within and outside the project. Gagnon [17] views the dissemination of knowledge and knowledge transfer as the same processes, through which the sources of the knowledge (individuals or organisations) communicate the knowledge to a particular target audience. Moreover, Gagnon [17] stated that producers of the knowledge "push (disseminate) knowledge toward audiences who they believe need to receive it" [17]. This view of knowledge dissemination resonates with the definition of 'knowledge sharing' by Szulanski [18], who specifically limits knowledge sharing to the knowledge exchanging behaviour of the knowledge source (provider).

The authors acknowledge that there is a difference between knowledge transfer and knowledge sharing as discussed in the literature. Knowledge transfer is more formal -knowledge is viewed as an object - whereas knowledge sharing is more informal - knowledge is viewed as a subjective and contextual construction [19]. For the purposes of this paper, knowledge sharing and knowledge transfer are viewed as the same thing and are used interchangeably. Taking the same view as Gagnon [17], this paper looks at knowledge dissemination from the 'push' perspective - that is, from the point of view of the knowledge source. In order to explore the factors that impact on knowledge dissemination, the authors first review the literature in the context of knowledge transfer, and then review the literature with an expert group to identify factors that are applicable to knowledge dissemination.

Schulze, Brojerdi and Von Krogh [20] highlighted that knowledge transfer success is limited at best. This emphasises the increased requirement to have knowledge transferred correctly for the receiver to be able to use it effectively. Cummings and Teng [21] also indicated that knowledge sharing proved to be more difficult than expected. Almeida and Soares [12] argued that knowledge is codified in the projects, and is hardly ever shared. They argued that knowledge sharing between 
project teams is ineffective, and that this is one of the key issues with which projects must deal. Argote, Ingram, Levin and Moreland [22] indicated that knowledge transfer is becoming increasingly important to organisations and projects. Studies in the medical field have also shown the need for knowledge dissemination. For example, Kamolratanakul, Ungtavorm and Israsena [14] stated that the "lack of knowledge and negative attitudes were the main reasons for refusal of the vaccination." Therefore knowledge sharing between doctor and patient is critical - all the more so in the medical field, where doctors work with people's lives.

One would also need to understand the ability of the source and the receiver to transfer, decode, and use the knowledge, along with their emotional intelligence. Fekete, Fekete and Greculescu [23] stated that, "according to the statistics, emotional competence is twice more important than technical or cognitive abilities. Emotional intelligence is the grasp and management of emotions in view of building congenial relationships with the people around us". Fekete et al. [23] indicated that emotional intelligence offers benefits to the organisation in the form of high performance, motivation and innovation, boost to self-confidence, efficient management, and teamwork. The experience of the source and the receiver plays a critical role in knowledge transfer, where experience is a key part of the knowledge management system, according to Parent, Macdonald and Goulet [24]. Knowing that there is a need to improve knowledge sharing and knowledge transfer, emotional intelligence and experience is required. One needs to determine what factors impact knowledge dissemination. Van den Hoff and de Ridder [25] acknowledge that an organisation's knowledge is becoming a key resource, and this needs to be managed effectively. This re-inforces the need to identify the factors that impact knowledge dissemination.

A number of studies since 1992 (for example, Zytowski [26]) have determined the factors that impact knowledge dissemination. These studies included the automotive, medical, psychological, and engineering industries, and some of them highlighted the following about knowledge dissemination:

Valerio, Passarella, Conti and Pagani [27] stated that, in accordance with the Bayesian cognitive models, "the basic idea is that people behave as intuitive statisticians, that is, their judgments closely correspond to the classical Bayesian statistical norms that explain how prior beliefs or hypothesis may be updated rationally in light of new information". From cognitive psychology, one understands the way people react to knowledge and how it influences the process of knowledge transfer. Fekete et al. [23] also touched on the psychological side. They indicated that scientific knowledge and emotional intelligence are key considerations for management to build congenial relationships with the people in the organisation and to enhance knowledge transfer. Emotional intelligence can offer benefits such as high performance, motivation, innovation, greater selfconfidence, efficient management, and teamwork.

Reed, Stringer, Fazey, Evely and Kruijsen [28] indicated that accumulating more knowledge does not necessarily translate into better practice. They added that the knowledge generated typically transforms into policy and procedure. Depending on how knowledge is produced and used, the knowledge can be translated, transformed, and shared for learning purposes. Most of what we learn, and the beliefs we hold, are formed in interactions with people. The knowledge is learned in a social context, or through books, the internet, and written or personal transfer. This is because we choose to trust the knowledge as valid and reliable. They add that this behaviour spreads out of empirical analyses in other contexts, including lobbying and the individual level of human behaviour.

We also know that knowledge transfer is the process through which one party is affected by the experience of another [29], and that when knowledge takes a tacit form, then knowledge transfer will not be as effective [30]. "Knowledge is usually defined as a justified belief that increases an entity's capacity to take effective action" [31]. There are currently high demands in the automotive industry and in the wider economy that require innovation in the industry, relying on contributions from different technological fields and more research and development alliances [20]. Knowledge sharing is not as easy as one would expect [21]. Parent et al. [24] supported the research of Hasnain and Jasimuddin [32], who argued that knowledge is one of the most valuable assets of an organisation. An organisation has definite goals to be met; so the successful transfer of knowledge from consultants (source) to the organisation (receiver) is critical to meeting these goals [33].

It is evident from the studies that the identified factors that impact knowledge dissemination also negatively impact the people, the teams, the organisations, and the communities when there is little or no knowledge dissemination. 
In order to identify the factors that impact knowledge dissemination and to answer research question 1 , an exploratory research approach was used to conduct a comprehensive qualitative literature study. Published journal articles were reviewed to identify factors that impact knowledge dissemination. A total of 104 published journal papers were reviewed, covering the automotive, medical, psychology-related, and engineering industries. Of the 104 journal papers, only 66 mentioned factors related to knowledge dissemination in a general context (i.e., not projectspecific). The literature review produced 36 factors that impact knowledge dissemination; these are summarised in Table 1 together with references to their sources.

\section{Table 1: Literature summary review of factors that impact knowledge dissemination}

\begin{tabular}{|c|c|c|c|}
\hline \# & $\begin{array}{l}\text { Factors that impact knowledge } \\
\text { dissemination }\end{array}$ & Literature reference & Comment \\
\hline 1 & Experience & $\begin{array}{l}{[22],[24],[29],[33],[34],} \\
{[35]}\end{array}$ & \\
\hline 2 & Allies \& relationship & {$[20],[33],[35]-[40]$} & \\
\hline 3 & Language \& articulability & {$[20],[23],[35],[41],[42]$} & \\
\hline 4 & Attainment of expert knowledge & $\begin{array}{l}{[20],[24],[33],[35],[36],} \\
{[43]}\end{array}$ & \\
\hline 5 & $\begin{array}{l}\text { Assessment of recipient's } \\
\text { knowledge base }\end{array}$ & {$[20],[33],[42]$} & combined in Factor 9 \\
\hline 6 & Detachment of knowledge & [20] & combined in Factor 9 \\
\hline 7 & $\begin{array}{l}\text { Ability to encode and decode } \\
\text { knowledge }\end{array}$ & $\begin{array}{l}\text { [12], [14], [20], [21], [25], } \\
{[33],[40]}\end{array}$ & combined in Factor 9 \\
\hline 8 & Support of knowledge application & {$[20],[24],[25]$} & combined in Factor 29 \\
\hline 9 & Disseminative capability & {$[20],[25],[30],[33],[42]$} & \\
\hline 10 & Knowledge transfer success & {$[20],[21],[29]$} & $\begin{array}{l}\text { Relevant to projects, but more an outcome } \\
\text { of knowledge dissemination }\end{array}$ \\
\hline 11 & Degree of modularisation & {$[20],[25],[44]$} & combined in Factor 31 \\
\hline 12 & Degree of innovation & {$[20],[23],[25],[33],[44]$} & combined in Factor 31 \\
\hline 13 & $\begin{array}{l}\text { Recipient firm's absorptive } \\
\text { capacity }\end{array}$ & {$[20],[25],[33],[40],[45]$} & combined in Factor 9 \\
\hline 14 & $\begin{array}{l}\text { Recipient's firm's transfer } \\
\text { experience }\end{array}$ & {$[20],[25],[35],[42],[45]$} & combined in Factor 9 \\
\hline 15 & Scale of tacit knowledge & {$[20],[30],[36]$} & \\
\hline 16 & Explicit knowledge & {$[20],[30],[36]$} & \\
\hline 17 & $\begin{array}{l}\text { Culture (diversity, learning, } \\
\text { distance, environment) }\end{array}$ & $\begin{array}{l}\text { [20], [21], [24], [25], [30], } \\
{[33],[38],[39],[46]}\end{array}$ & \\
\hline 18 & Emotional competence & {$[23]$} & \\
\hline 19 & $\begin{array}{l}\text { Distance (organisational, physical, } \\
\text { knowledge, norm) }\end{array}$ & [21], [39], [40], [45], [46] & \\
\hline 20 & Priority & [21] & \\
\hline 21 & Project performance & {$[21],[23],[25],[29],[35]$} & \\
\hline 22 & Organisational tenure & {$[24],[29],[39],[45],[47]$} & combined in Factor 29 \\
\hline 23 & $\begin{array}{l}\text { Advancement within the } \\
\text { organisation }\end{array}$ & {$[24],[25],[29]$} & combined in Factor 29 \\
\hline 24 & Trust & {$[25],[28],[29],[35],[38]$} & \\
\hline 25 & Value & $\begin{array}{l}{[21],[29],[37],[42],[43],} \\
{[47]}\end{array}$ & \\
\hline 26 & Source credibility & [33], [42] & \\
\hline 27 & Shared understanding & $\begin{array}{l}{[30],[33],[35],[36],[38],} \\
{[39]}\end{array}$ & \\
\hline 28 & Motivation & [21], [23], [25], [33] & \\
\hline 29 & Organisation's commitment & [21], [25], [33], [42] & \\
\hline 30 & Organisation's communication & $\begin{array}{l}\text { [21], [24], [25], [29], [33], } \\
{[35],[39],[45],[47]}\end{array}$ & combined in Factor 3 \\
\hline 31 & Technology \& tools & $\begin{array}{l}{[24],[25],[30],[39],[41]-} \\
{[44],[46]}\end{array}$ & \\
\hline 32 & Organisational climate & $\begin{array}{l}{[21],[29],[37],[42],[43],} \\
{[47]}\end{array}$ & combined in Factor 17 \\
\hline 33 & Team size & {$[24],[25],[30],[37],[43]$} & \\
\hline 34 & Frequency of knowledge re-use & [35] & \\
\hline 35 & Organisational restructuring & [25], [29] & \\
\hline 36 & Embeddedness & [45] & \\
\hline
\end{tabular}


Knowledge management $(\mathrm{KM})$ in developing countries has been too seldom studied. A meta-analysis over a 34-year period reveals that only eight per cent of the total of 1,043 articles on KM were published in Africa [48]. Moreover, the studies provided evidence that projects on the African continent fail in both public and private sectors [49]. This points to the need for more empirical studies in Africa. Therefore, South Africa, as a representative of a developing country in Africa, was chosen for this study.

Selected interviews were conducted with an expert group to evaluate and short-list the factors that impact knowledge dissemination on projects, to optimise the relevance of the identified factors for application in project environments. The expert group consists of two academics and four experts from industry, with an average project experience of 14 years. Through this expert group, the original list of factors was reduced to 30 factors that are relevant to projects. The final list of factors and the glossary used in this study is given in Table 2.

Table 2: Final list of factors that impact knowledge dissemination

\begin{tabular}{|c|c|c|}
\hline \# & Factors & Glossary \\
\hline 1 & $\begin{array}{l}\text { Experience } \\
\text { (Individual) }\end{array}$ & $\begin{array}{l}\text { The experience that the individual gains to complete the required tasks } \\
\text { successfully }\end{array}$ \\
\hline 2 & Experience (Company) & $\begin{array}{l}\text { The experience that the company gains to complete the required tasks } \\
\text { successfully }\end{array}$ \\
\hline 3 & $\begin{array}{l}\text { Allies \& formal } \\
\text { relationship }\end{array}$ & The formal relationship and alliance between the source and the receiver \\
\hline 4 & Language & $\begin{array}{l}\text { To be able to transfer knowledge clearly and in a language that the receiver can } \\
\text { understand }\end{array}$ \\
\hline 5 & Articulability & The ability of the source to transfer knowledge in a clearly expressed way \\
\hline 6 & $\begin{array}{l}\text { Attainment of expert } \\
\text { knowledge }\end{array}$ & Obtaining expert knowledge to support knowledge dissemination \\
\hline 7 & $\begin{array}{l}\text { Disseminative } \\
\text { capability }\end{array}$ & $\begin{array}{l}\text { Assessment of recipient's knowledge, detachment of knowledge, ability to } \\
\text { encode and decode knowledge }\end{array}$ \\
\hline 8 & $\begin{array}{l}\text { Explicitness of } \\
\text { knowledge }\end{array}$ & How well one can move from tacit to explicit knowledge. \\
\hline 9 & Culture (Person) & The cultural background of the person \\
\hline 10 & Culture (Company) & The culture created within a company \\
\hline 11 & Culture (National) & The national cultural difference \\
\hline 12 & Culture (International) & The International cultural difference \\
\hline 13 & Emotional intelligence & The ability to control one's emotions \\
\hline 14 & $\begin{array}{l}\text { Distance } \\
\text { (Geographical) }\end{array}$ & The geographical distance between source and recipient \\
\hline 15 & Priority (General) & The priority of the project or the priority of the task \\
\hline 16 & Project performance & $\begin{array}{l}\text { Project performance in relation to perceived value contained, client } \\
\text { satisfaction and project deliverables being met in respect of time, cost and } \\
\text { quality }\end{array}$ \\
\hline 17 & Trust & Trust between members, and between sources and the recipient \\
\hline 18 & Value of knowledge & The value of knowledge as perceived by the receiver \\
\hline 19 & Source credibility & $\begin{array}{l}\text { The extent to which a recipient perceives a source to be trustworthy and an } \\
\text { expert }\end{array}$ \\
\hline 20 & Shared understanding & $\begin{array}{l}\text { The common understanding between the source and the receiver about the } \\
\text { knowledge being transferred }\end{array}$ \\
\hline 21 & Motivation & Motivation among team members that enables knowledge transfer \\
\hline 22 & $\begin{array}{l}\text { Organisation's } \\
\text { commitment }\end{array}$ & $\begin{array}{l}\text { Organisational commitment to knowledge dissemination and to supporting } \\
\text { knowledge transfer }\end{array}$ \\
\hline 23 & Technology \& tools & $\begin{array}{l}\text { Technology and tools used within projects to promote and support knowledge } \\
\text { transfer from the source to the receiver }\end{array}$ \\
\hline 24 & Team size (Source) & The size of the team of the source that transfers knowledge \\
\hline 25 & Team size (Receiver) & The size of the team of the receiver to which knowledge is being transferred \\
\hline 26 & $\begin{array}{l}\text { Frequency of } \\
\text { knowledge use }\end{array}$ & The frequency of the knowledge being used by the receiver \\
\hline 27 & $\begin{array}{l}\text { Organisational } \\
\text { restructuring }\end{array}$ & Restructuring of the organisational resources and structures \\
\hline 28 & Embeddedness & $\begin{array}{l}\text { Embeddedness of knowledge within an organisation's systems, processes, } \\
\text { people, and structures }\end{array}$ \\
\hline 29 & Noise & The transfer of less useful information \\
\hline 30 & Volume of knowledge & The amount of knowledge to be transferred at a specific point in time \\
\hline
\end{tabular}


To be able to answer research question 2, the final list of factors was evaluated in terms of impact, using a survey questionnaire. Each factor was rated on a four-point Likert scale that is ordinal in nature (where ' 1 ' means no impact and ' 4 ' means a major impact). A non-parametric test is therefore needed to compare the ranking among the factors. Friedman's test - as the nonparametric alternative to the one-way ANOVA with repeated measures - was used to determine the differences between the factors' mean ranks. A chi-square test that determines whether the differences in the mean ranks among the factors are statistically significant or not was also used.

The survey questionnaire was distributed among project managers and project team members through a web-based questionnaire tool, using the snowball sampling technique. Based on the rated impact of factors, a list of critical factors that impact knowledge dissemination on projects from the knowledge source point of view can be identified. It can also possibly be used for further studies and to improve knowledge dissemination within projects.

\section{RESULTS}

The survey response was well-received, with a total of 129 respondents participating from 42 different companies, exceeding the minimum sample size of 30 for Friedman's test. The background of the respondents and their involvement in project management is reported below.

Of the 129 respondents who completed the survey, 74 per cent were male respondents and 26 per cent were female. The respondents' ages were evenly distributed between 20 and $50+$, with the majority of respondents being between 30 and 39 ( 46.5 per cent). Their level of management is also fairly evenly distributed, with 36 per cent being middle management. The majority of respondents were from the engineering (40 per cent) and management (15.5 per cent) disciplines, with the majority educated beyond matric $(77.5$ per cent). It also illustrated that the respondents work with up to 19 members in their team (71 per cent), with project size ranging from small (up to $\$ 4.9$ million) (29.5 per cent), medium (up to $\$ 29.9$ million) (35.7 per cent), and large projects (between R300 / \$30 and R900 / \$90 million) (18.6 per cent). Only 16.3 per cent of the respondents work on mega-projects (above $\$ 100$ million). These attributes show that the result of this study (prioritising of factors) is not biased towards a specific category of respondents or project size.

The responses from the survey and the critical factors are listed in Table 3. Factors with higher mean rank values are considered to have the most impact on knowledge dissemination. The Chisquare value is 600.257 , with a significant value of $p=0.000$. This indicates that there is a significant difference among the factors in terms of mean ranks.

Table 3: Factors ranked according to the mean rank

\begin{tabular}{|c|l|l|l|}
\hline$\#$ & Factor & Factor glossary used within the survey & $\begin{array}{l}\text { Mean } \\
\text { rank }\end{array}$ \\
\hline Critical factors & $\begin{array}{l}\text { Experience } \\
\text { (individual) }\end{array}$ & $\begin{array}{l}\text { The experience that the individual (source) obtained to complete the } \\
\text { required tasks successfully }\end{array}$ & 19.50 \\
\hline 2 & $\begin{array}{l}\text { Experience } \\
\text { (Company) }\end{array}$ & $\begin{array}{l}\text { The experience that the company (source) obtained to complete the } \\
\text { required tasks successfully }\end{array}$ & 19.28 \\
\hline 21 & Motivation & Motivation among team members that enables knowledge transfer & 19.21 \\
\hline 20 & $\begin{array}{l}\text { Shared } \\
\text { understanding }\end{array}$ & $\begin{array}{l}\text { The common understanding between the source and the receiver } \\
\text { about the knowledge being transferred }\end{array}$ & 19.07 \\
\hline 17 & Trust & Trust between members, as well as between source and recipient & 19.06 \\
\hline 19 & Source credibility & $\begin{array}{l}\text { The extent to which a recipient perceives a source to be trustworthy } \\
\text { and an expert }\end{array}$ & 18.75 \\
\hline 22 & $\begin{array}{l}\text { Organisation's } \\
\text { commitment }\end{array}$ & $\begin{array}{l}\text { Organisational commitment to knowledge dissemination and to } \\
\text { supporting knowledge transfer }\end{array}$ & 18.38 \\
\hline 5 & Articulability & $\begin{array}{l}\text { The ability of the source to transfer knowledge in a clearly expressed } \\
\text { way }\end{array}$ & 18.06 \\
\hline 16 & $\begin{array}{l}\text { Project } \\
\text { performance }\end{array}$ & $\begin{array}{l}\text { Project performance in relation to perceived value contained, client } \\
\text { satisfaction, and project deliverables being met in respect of time, } \\
\text { cost, and quality }\end{array}$ & 17.94 \\
\hline 18 & $\begin{array}{l}\text { Value of } \\
\text { knowledge }\end{array}$ & The value of knowledge as perceived by the receiver & 17.66 \\
\hline
\end{tabular}


Table 3 (cont.): Factors ranked according to the mean rank

\begin{tabular}{|c|c|c|c|}
\hline \multicolumn{4}{|c|}{ Near critical factors } \\
\hline 3 & $\begin{array}{l}\text { Allies \& formal } \\
\text { relationships }\end{array}$ & $\begin{array}{l}\text { The formal relationship and alliance between the source and the } \\
\text { receiver }\end{array}$ & 17.36 \\
\hline 4 & Language & $\begin{array}{l}\text { To be able to transfer knowledge clearly and in a language that the } \\
\text { receiver can understand }\end{array}$ & 17.33 \\
\hline 6 & $\begin{array}{l}\text { Attainment of expert } \\
\text { knowledge }\end{array}$ & Obtaining expert knowledge to support knowledge dissemination & 16.65 \\
\hline 27 & $\begin{array}{l}\text { Organisational } \\
\text { restructuring }\end{array}$ & Restructuring of the organisation's resources and structures & 16.25 \\
\hline 15 & Priority (General) & The priority of the project or the priority of the task & 16.06 \\
\hline 7 & $\begin{array}{l}\text { Disseminative } \\
\text { capability }\end{array}$ & $\begin{array}{l}\text { Assessment of recipient's knowledge, detachment of knowledge, and } \\
\text { ability to encode and decode knowledge (sender) }\end{array}$ & 16.00 \\
\hline 23 & Technology \& tools & $\begin{array}{l}\text { Technology and tools used within projects to promote and support } \\
\text { knowledge transfer from the source to the receiver }\end{array}$ & 15.97 \\
\hline 28 & Embeddedness & $\begin{array}{l}\text { Embeddedness of knowledge within an organisation's systems, } \\
\text { processes, people, and structures }\end{array}$ & 15.60 \\
\hline 13 & $\begin{array}{l}\text { Emotional } \\
\text { intelligence }\end{array}$ & The ability to control one's emotions & 15.47 \\
\hline 8 & $\begin{array}{l}\text { Explicitness of } \\
\text { knowledge }\end{array}$ & $\begin{array}{l}\text { How well one can move from tacit to explicit knowledge. Tacit } \\
\text { knowledge cannot be written down easily, while explicit knowledge } \\
\text { can be written down easily }\end{array}$ & 15.06 \\
\hline 30 & Volume of knowledge & The amount of knowledge to be transferred at a specific point in time & 15.00 \\
\hline 10 & Culture (Company) & The underlying organisational culture and value system & 14.53 \\
\hline 26 & $\begin{array}{l}\text { Frequency of } \\
\text { knowledge use }\end{array}$ & The frequency of the knowledge being used by the receiver & 13.78 \\
\hline 14 & $\begin{array}{l}\text { Distance } \\
\text { (Geographical) }\end{array}$ & The geographical distance between source and recipient & 11.04 \\
\hline 12 & $\begin{array}{l}\text { Culture } \\
\text { (International) }\end{array}$ & $\begin{array}{l}\text { The international cultural difference between project team members } \\
\text { participating on projects }\end{array}$ & 10.94 \\
\hline 25 & Team size (Receiver) & $\begin{array}{l}\text { The size of the team of the receiver to whom knowledge is being } \\
\text { transferred }\end{array}$ & 10.80 \\
\hline 24 & Team size (Source) & The size of the team of the source that transfers knowledge & 10.38 \\
\hline 29 & Noise & The transfer of less useful information & 10.25 \\
\hline 9 & Culture (Person) & The cultural background of the person & 10.25 \\
\hline 11 & Culture (National) & $\begin{array}{l}\text { The national cultural difference between project team members } \\
\text { participating on projects }\end{array}$ & 9.38 \\
\hline
\end{tabular}

\section{CONCLUSIONS AND RECOMMENDATIONS}

\subsection{Conclusion}

The objectives defined for this research through the empirical study, qualitative literature review, interviews, survey, and analysis of the results were achieved, with the list of critical factors impacting knowledge dissemination from the source being identified and listed in accordance with critical and near-critical factors that will positively contribute to research and the project environment.

The summary of factors that impact knowledge dissemination on projects is illustrated by the following figure, from the critical factors to the near-critical factors: 


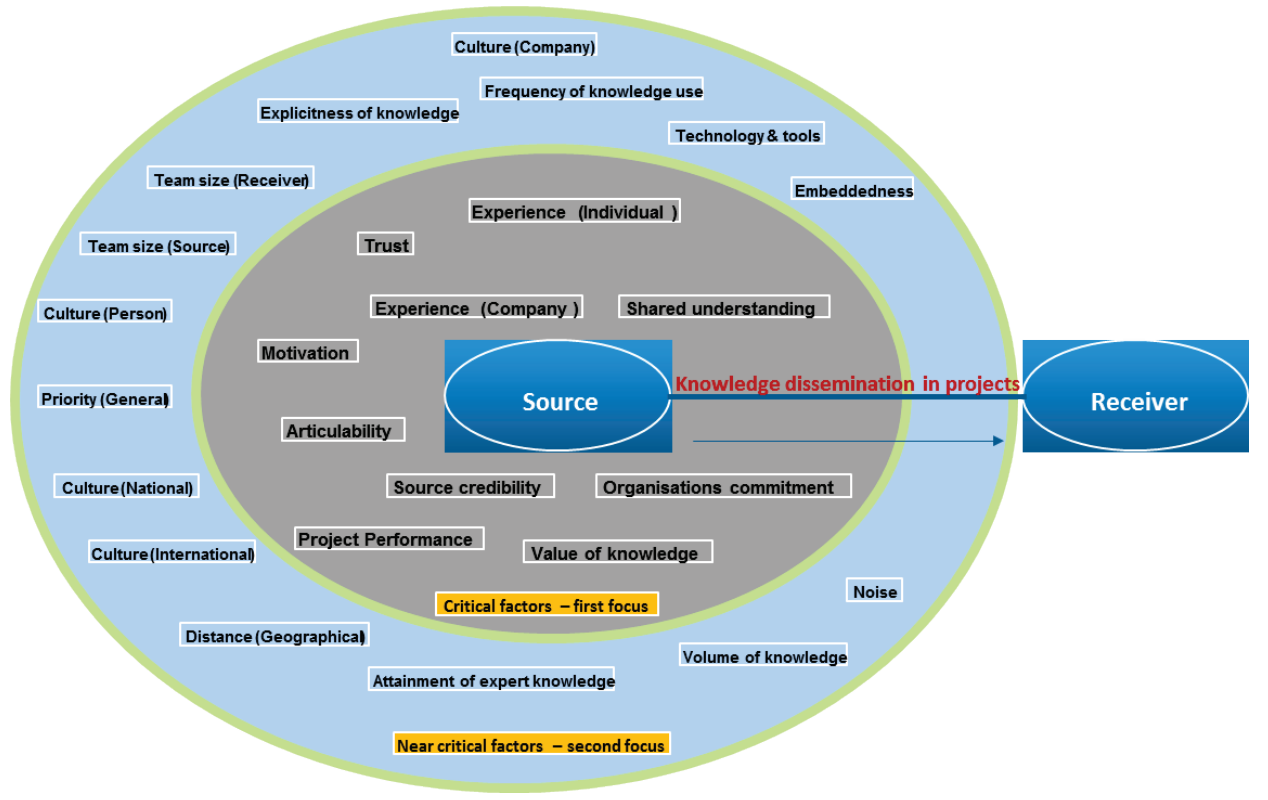

Figure 1: Summary of factors that impact knowledge dissemination on projects from the source

The above figure highlights the flow of knowledge dissemination from the source to the receiver and the associated factors that impact knowledge dissemination in projects. The list of factors in the inner circle (as depicted in Figure 1 above) can be seen as the critical factors, with the remaining factors being the near-critical factors in the outer circle. With no significant difference between the factors, and no priority emerging among the top ten factors (no single factor had a bigger impact than the others), the principle of 'critical path' can be applied to the factors listed, with the main focus being on the critical path - in this case, the critical factors. The near-critical path also enjoys focus, but not as much as the critical path. In this instance, it is the near-critical factor. The near critical-factors cannot be neglected, for they have the potential to become critical factors.

This research finding has some managerial implications. The critical factors identified in this study suggest that knowledge dissemination in the project environment is mainly influenced by individual factors (such as individual experience, articulability, trust, and motivation) rather than by other factors that relate to organisation, knowledge, or project characteristics. This finding coincides with the empirical research of Zuraini and Aris [50], who found that, compared with organisational factors, knowledge sharing is mainly influenced by individual factors - namely, self-worth and attitudes. They argued that knowledge is generated and resides in people [51], and thus individuals' knowledge sharing behaviours are more dominantly dependent on the individual's sense of selfworth and attitudes.

The individual's experience and credibility as critical factors in this study are related to self-worth, which is defined as "what people thought about themselves" [50, p.8]. Once people gain experience in executing project-related tasks, they feel more competent and, as a result, feel more confident about sharing what they know about the project with other team members. The credibility of the knowledge source comes with the experience that they have obtained. Moreover, the source's experience with knowledge sharing may influence their motivation for autonomous knowledge sharing in the future [52]. The organisation can establish a mentoring and coaching programme to support the individuals in building their experience of completing tasks in projects, or in the ability to express themselves clearly when sharing knowledge with other team members (articulability). To build the knowledge sources' credibility among the project teams, the management should promote the individuals and their field of expertise in the organisation so that other project team members come to recognise them as experts.

Trust and motivation (both relating to individuals' attitudes) are found to be critical in this study. These two factors impact on a person's willingness to share knowledge with another person. 
Interpersonal trust is a prerequisite for knowledge sharing [53]. In a project environment, teams are temporary in nature; and so trust and shared understanding cannot be as easily built over a short period of time as with a permanent team. Moreover, individuals may not willingly trust and engage knowledge sharing behaviours if they do not have a history of working with other project team members [54]. It is recommended in this study that, when designing a project team's composition, one should take into account the existing relationships among team members. In a project team whose tasks are interdependent, there is a higher task cohesion within the team [55], and its members are motivated to disseminate knowledge to others in order to complete the tasks required. Thus, project managers should to inform team members clearly, and stress the importance of task dependency in the projects in order to motivate them in knowledge sharing.

\subsection{Recommendations for further research}

The research contributed to identifying the list of critical factors that impact knowledge dissemination in projects from the knowledge source point of view. Given the methodology and research design followed in this study and its limitations, further research could be conducted to evaluate the different responses received in relation to the different areas - for example, engineering vs non-engineering, client vs contractor, size of the project, team size, and management responses; to create and test a model that will address the list of factors that impact knowledge dissemination in projects; to test the list of factors among project team members in Africa; to test the list of factors among international project team members; to test the list of factors among multi-international project team members; and to evaluate the factors that impact knowledge dissemination across the different phases of a project.

\section{REFERENCES}

[1] Sankarasubramanian, S. 2009. Knowledge management meets project management. Project Management Institute.

[2] Davenport, T.H. and Prusak, L. 1998. Working knowledge: How organizations manage what they know. Harvard Business Press.

[3] Fong, P.S.W. 2005. Co-creation of knowledge by multidisciplinary project teams, in Management of Knowledge in Project Environment, P.E. Love, P.S.W. Fong and Z. Irani (eds). Oxford: Elsevier Ltd, pp. 4156.

[4] Hanisch, B., Lindner, F., Mueller, A. and Wald, A. 2009. Knowledge management in project environments, Joutnal of Knowledge Management, 13(4), pp. 148-160.

[5] Schindler, M. and Eppler, M.J. 2003. Harvesting project knowledge: A review of project learning methods and success factors, International Journal of Project Management, 21(3), pp. 219-228.

[6] O'Dell, C. and Grayson, C.J. 1998. If we only knew what we know: The transfer of internal knowledge, California Management Review, 40(3), pp. 154-174.

[7] Kingston, J. 2012. Choosing a knowledge dissemination approach, Knowledge and Process Management, 19(3), pp. 160-170.

[8] Busby, J.S. 1999. An assessment of post-project reviews, International Journal of Project Management, 30(3), pp. 23-29.

[9] Lin, Y. and Taylor, H. 2009. An organizational memory approach to the knowledge dissemination of postproject reviews: Combining knowledge management and organizational learning, International Research Workshop on IT Project Management, p. 5.

[10] Ajmal, M., Helo, P. and Kekäle, T. 2010. Critical factors for knowledge management in project business, Journal of Knowledge Management, 14(1), pp. 156-168.

[11] Boh, W.F. 2007. Mechanisms for sharing knowledge in project-based organizations, Information and Organization, 17(1), pp. 27-58.

[12] Almeida, M.V. and Soares, A.L. 2014. Knowledge sharing in project-based organizations: Overcoming the informational limbo, International Journal of Information Management, 34(6), pp. 770-779.

[13] Pinto, M.B. and Pinto, J.K. 1990. Project team communication and cross-functional cooperation in new program development, Journal of Product Innovation Management, 7(3), pp. 200-212.

[14] Kamolratanakul, P., Ungtavorn, P. and Israsena, S., Sakulrarnrung, R. 1994. The influence of dissemination of information on the changes of knowledge, attitude and acceptance of Hepatitis $B$ vaccination among hospital personnel in Chulalongkorn Hospital, Public Health, 108(1), pp. 49-53.

[15] Brookes, N.J., Morton, S.C., Dainty, A.R.J. and Burns, N.D. 2006. Social processes, patterns and practices and project knowledge management: A theoretical framework and an empirical investigation, International Journal of Project Management, 24(6), pp. 474-482.

[16] Kasvi, J.J.J., Vartiainen, M. and Hailikari, M. 2003. Managing knowledge and knowledge competences in projects and project organisations, International Journal of Project Management, 21(8), pp. 571-582.

[17] Gagnon, M.L. 2011. Moving knowledge to action through dissemination and exchange, Jounral of Clinical Epidemiology, 64(1), pp. 25-31.

[18] Szulanski, G. 1996. Exploring internal stickiness: Impediments to the transfer of best practice within the firm, Strategic Management Journal, 17(S2), pp. 27-43. 
[19] Paulin, D. and Suneson, K. 2012. Knowledge transfer, knowledge sharing and knowledge barriers: Three blurry terms in KM, Electronic Journal of Knowledge Management, 10(1), pp. 81-91.

[20] Schulze, A., Brojerdi, G. and Von Krogh, G. 2014. Those who know, do. Those who understand, teach. Disseminative capability and knowledge transfer in the automotive industry, Journal of Product Innovation Management, 31(1), pp. 79-97.

[21] Cummings, J.L. and Teng, B.S. 2003. Transferring R \& D knowledge: The key factors affecting knowledge transfer success, Journal of Engineering and Technology Management, 20(1-2 SPEC.), pp. 39-68.

[22] Argote, L., Ingram, P., Levine, J.M. and Moreland, R.L. 2000. Knowledge transfer in organizations: Learning from the experience of others, Organizational Behavior and Human Decision Processes, 82(1), pp. 1-8.

[23] Fekete, A., Fekete, M. and Greculescu, A. 2014. Factors influencing psychosocial communication in the reason / emotion society, Procedia - Social and Behavioral Sciences, 128, pp. 123-127.

[24] Parent, M.M., Macdonald, D. and Goulet, G. 2014. The theory and practice of knowledge management and transfer: The case of the Olympic Games, Sport Management Review, 172, pp. 205-218.

[25] Van den Hooff, B. and de Ridder, J.A. 2004. Knowledge sharing in context: The influence of organizational commitment, communication climate and CMC use on knowledge sharing, Journal of Knowledge Management, 8(6), pp. 117-130.

[26] Zytowski, D.G. 1992. Let's make knowledge dissemination as good as knowledge production, Journal of Vocational Behavior, 40(2), pp. 207-209.

[27] Valerio, L., Passarella, A., Conti, M. and Pagani, E. 2015. Scalable data dissemination in opportunistic networks through cognitive methods, Pervasive Mobile Computing, 16, pp. 115-135.

[28] Reed, M.S., Stringer, L.C., Fazey, I., Evely, A.C. and Kruijsen, J.H.J. 2014. Five principles for the practice of knowledge exchange in environmental management, Journal of Environmental Management, 146, pp. 337-345.

[29] Watson, S. and Hewett, K. 2006. A multi-theoretical model of knowledge transfer in organizations: Determinants of knowledge contribution and knowledge re-use, Journal of Management Studies, 43(2), pp. 141-173.

[30] Mabey, C. and Nicholds, A. 2015. Discourses of knowledge across global networks: What can be learnt about knowledge leadership from the ATLAS collaboration?, International Business Review, 24(1), pp. 4354.

[31] Alavi, M. and Leidner, D.E. 2001. Review: Knowledge management and knowledge management systems: Conceptual foundations and research issues, MIS Quarterly, 25(1), pp. 107-136.

[32] Hasnain, S.S. and Jasimuddin, S.M. 2012. Barriers to knowledge transfer: Empirical evidence from the NGO (non-governmental organizations) sector in Bangladesh, World Journal of Social Science, 2(2), pp. 135-150.

[33] Ko, D.-G., Kirsch, L.J. and King, W.R. 2005. Antecedents of knowledge transfer from consultants to clients in enterprise system implementations, MIS Quarterly, 29(1), pp. 59-85.

[34] Joubert, M. 2010. Teachers as facilitators, University of Pretoria.

[35] Lee, J., Park, J.-G. and Lee, S. 2015. Raising team social capital with knowledge and communication in information systems development projects, International Journal of Project Management, 334, pp. 797807.

[36] Söderquist, K.E. 2006. Organising knowledge management and dissemination in new product development: Lessons from 12 global corporations, Long Range Planning, 39(5), pp. 497-523.

[37] Achcaoucaou, F., Miravitlles, P. and León-Darder, F. 2014. Knowledge sharing and subsidiary R\&D mandate development: A matter of dual embeddedness, International Business Review, 23(1), pp. 76-90.

[38] Inkpen, A.C. and Tsang, E.W.K. 2005. Social capital, networks and knowledge transfer, Academy of Management Review, 30(1), pp. 146-165.

[39] Schomaker, M.S. and Zaheer, S. 2014. The role of language in knowledge transfer to geographically dispersed manufacturing operations, Journal of International Management, 20(1), pp. 55-72.

[40] Gurrieri, A.R. 2008. Knowledge network dissemination in a family-firm sector, Journal of Socio-Economics, 37(6), pp. 2380-2389.

[41] Molesworth, B.R.C. and Estival, D. 2015. Miscommunication in general aviation: The influence of external factors on communication errors, Safety Science, 73, pp. 73-79.

[42] Mueller, H. and Nyfeler, T. 2011. Quality in patent information retrieval: Communication as the key factor, World Patent Information, 33(4), pp. 383-388.

[43] Shafran, R. et al. 2009. Mind the gap: Improving the dissemination of CBT, Behaviour Research and Therapy, 47(11), pp. 902-909.

[44] Akin, 0. 2005. Digital knowledge dissemination, Automation in Construction, 14(6), pp. 687-688.

[45] Lodhia, S. 2014. Factors influencing the use of the World Wide Web for sustainability communication: An Australian mining perspective, Journal of Cleaner Production, 84, pp. 142-154.

[46] Ambos, T.C. and Ambos, B. 2009. The impact of distance on knowledge transfer effectiveness in multinational corporations, Journal of International Management, 15(1), pp. 1-14.

[47] Karanges, E., Johnston, K., Beatson, A. and Lings, I. 2015. The influence of internal communication on employee engagement: A pilot study, Public Relations Review, 41(1), pp. 129-131.

[48] Dwivedi, Y.K., Venkitachalam, K., Sharif, A.M., Al-Karaghouli, W. and Weerakkody, V. 2011. Research trends in knowledge management: Analyzing the past and predicting the future, Information Systems Management, 28(1), pp. 43-56.

[49] Rwelamila, P.D. and Purushottam, N. 2012. Project management trilogy challenges in Africa: Where to from here?, Project Management Journal, 43(4), pp. 5-13. 
[50] Zuraini, A. and Aris, Z. 2014. Examining relationships between individual, organisational factors and knowledge sharing behaviour, University Utara Malaysia.

[51] Kessels, J.W. and Harrison, R. 2004. Human resource development in a knowledge economy: An organisational view. New York: Palgrave Macmillan.

[52] Reinholt, M., Pedersen, T. and Foss, N.J. 2011. Why a central network position isn't enough: The role of motivation and ability for knowledge sharing in employee networks, Academy of Management Journal, 54(6), pp. 1277-1297.

[53] Holste, J.S. and Fields, D. 2010. Trust and tacit knowledge sharing and use, Journal of Knowledge Management, 14(1), pp. 128-140.

[54] Ipe, M. 2003. Knowledge sharing in organizations: A conceptual framework, Human Resource Development Review, 2(4), pp. 337-359.

[55] Chiocchio, F. and Essiembre, H. 2009. Cohesion and performance: A meta-analytic review of disparities between project teams, production teams, and service teams, Small Group Research, 40(4), pp. 382-420. 